\title{
HOMOSSEXUALIDADE, GÊNERO E CURA EM PERSPECTIVAS PASTORAIS EVANGÉLICAS
}

\author{
Marcelo Natividade
}

[...] eu vi lágrimas naquele rosto. Vi, sim, rosto de mulher. Ou quem sabe era homem? Não dava pra dizer o certo. Mas chorava. Certeza, eu só tive uma: era entendido. Entendido em sofrimento, em dor, em ser magoado, saber direitinho

o que é bumilhação, vexame, até pancada. Entendido em perder... Alguns perderam a digni-

* Agradeço à Associação Nacional de Pós-Graduação e Pesquisa em Ciências Sociais (Anpocs), ao Centro Latino Americano em Sexualidade e Direitos Humanos (IMS/Uerj) e à Capes por terem propiciado, em diferentes momentos, suporte para realização de pesquisa da qual este trabalho faz parte.

Artigo recebido em março/2005

Aprovado em maio/2005 dade; outros até a própria vontade de viver. Entendido em preconceito no trabalho, nas ruas, na familia, na igreja. Entendido em AIDS. Entendido em ouvir deboches na rua e caminhar de cabeça baixa, tentando não ser notado. Ou arrogantemente, com a cabeça erguida, olhando desafiadoramente para as pessoas, disposto a agredir antes de ser agredido... Entendido em disfarces, mentiras. E muitas vezes quando olha no espelho, não se vê homem nem tão pouco mulher. E descobre que não é nada. Não é bomem nem mulber. JuLIO SEVERO, ESCRITOR EVANGÉLICO

Em agosto de 2004, um projeto em tramitação na Assembléia Legislativa do Estado do Rio de Janeiro chamou a atenção da opinião pública e desdobrou-se em delicada controvérsia sobre a possibilidade de mudança da orientação sexual dos homossexuais. ${ }^{1}$ À época, desenvolvia uma pesquisa 
sobre as concepções da homossexualidade entre evangélicos na cidade do Rio de Janeiro. Ao acompanhar a atuação de grupos religiosos como o Movimento pela Sexualidade Sadia (Moses), o Corpo de Psicólogos e Psiquiatras Cristãos (CPPC) e a Associação Brasileira de Apoio a Pessoas que Voluntariamente Desejam Deixar a Homossexualidade (ABRACEH), ${ }^{2}$ entrevistava homens pertencentes a comunidades pentecostais que já haviam mantido relacionamentos homossexuais ao longo de suas vidas, buscando investigar os nexos entre a experiência religiosa e os processos de construção de si. $^{3}$

$\mathrm{Na}$ primeira etapa da pesquisa, o discurso religioso que contemplava a noção de cura da homossexualidade apareceu como perspectiva hegemônica, ${ }^{4}$ defendida por diferentes denominações, apesar das variadas ênfases cosmológicas e doutrinárias destas igrejas. 5 Assegurando a possibilidade da "transformação" dos indivíduos em ex-homossexuais - enunciada na esfera pastoral como uma "esperança àqueles que sofrem" -, a fala dos religiosos adentrava a arena política em um projeto que previa a alocação de recursos estatais para iniciativas religiosas voltadas à recuperação de homossexuais. Um deputado religioso chegou a conceder parecer favorável ao projeto nos seguintes termos:

Homem e mulher foram criados e nasceram com sexos opostos para se complementarem e se procriarem. O homossexualismo apesar de aceito pela sociedade é uma distorção da natureza do ser humano normal. Assim, a oportunidade de se apostar novamente na condição normal de procriação é louvável e por isso meu parecer é favorável (Deputado S. Malafaia-Relator).

O tema repercutiu na grande imprensa e contou com a reação de diversos setores da sociedade civil: movimentos sociais, intelectuais, personalidades públicas e ONGs manifestaram seu repúdio ao fundamentalismo e à homofobia dos evangélicos. O debate demonstrou a necessidade premente de investigação das perspectivas religiosas no que se refere à sexualidade no Brasil contemporâneo.

A produção antropológica voltada às esferas do entrelaçamento entre religião e sexualidade ressalta os impactos da adesão religiosa sobre a construção do gênero e da sexualidade feminina (Machado, 1996; Machado e Mariz, 1996). Embora alguns estudos tematizem determinados aspectos da regulação da sexualidade pelas doutrinas evangélicas, pouco tem sido escrito especificamente sobre a homossexualidade. Este artigo pretende contribuir para esse debate, enfocando discursos sobre práticas homossexuais em perspectivas pastorais e doutrinárias evangélicas.

Pesquisas recentes apontam para transformações no panorama religioso brasileiro em relação a temáticas pertinentes à esfera da sexualidade como, por exemplo, a exigência de fidelidade para homens e mulheres, indicando uma minimização da assimetria entre os gêneros (Machado, 1996; Fernandes et al, 1998). No contexto evangélico, em questões como aborto, homossexualidade e escolha sexual parece haver certa impermeabilidade à mudança (Mafra, 1998). A despeito de uma ênfase no discurso de acolbida, permanece a idéia de que tais práticas são pecaminosas. Assim, ainda que a Igreja Universal do Reino de Deus (Iurd) se destaque em um conjunto mais amplo de comunidades religiosas pela maior aceitação de homossexuais em seu quadro de fiéis $(76 \%$ dos entrevistados dessa igreja afirmou que jamais excluiria um homossexual do espaço congregacional), a defesa desta atitude deve ser vista menos como aceitação da prática homossexual e mais como "motivo primeiro para um cuidado pastoral" (Fernandes et al., 1998, p. 117).

Essa postura pastoral propicia uma proliferação das falas que opera como uma verdadeira explosão discursiva (Foucault, 1997). O foco de interesse deste artigo é direcionado às perspectivas de gerenciamento das práticas sexuais a partir de um determinado discurso sobre a homossexualidade. Trata-se de discutir, sobretudo, os nexos entre as concepções de corpo, gênero e sexualidade presentes no discurso religioso.

A proposta insere-se em uma abordagem antropológica que privilegia a construção social e cultural da sexualidade. Tem-se como pressuposto básico o fato de a conduta sexual ser um domínio que depende da socialização e da atribuição de significados, regulada por parâmetros sociais (Heilborn, 1999; Weeks, 1999). Considero a religião como uma dessas instâncias de controle, 
visto que constitui sistemas simbólicos capazes de fornecer sentido à ação social, introduzindo disposiçôes e motivações, um certo modo de ver, apreender e entender o mundo (Geertz, 1989). Nesse sentido, compreender que valores são difundidos pelo discurso religioso contribui para o desvelar das lógicas culturais que informam a experiência e orientam a ação social (Fry, 1982).

$\mathrm{Na}$ primeira parte, trato das formas de problematização da homossexualidade em discursos religiosos brasileiros. Na segunda, o foco é dirigido às técnicas que compõem o discurso sobre cura e libertação da homossexualidade, com vistas a compreender quais as perspectivas de regulação da sexualidade neste contexto.

Antes de proceder à análise do discurso evangélico cabe uma contextualização do material etnográfico. Os textos que focalizo na primeira parte contemplam a produção discursiva evangélica brasileira sobre o tema. Recolhidos a partir de um mapeamento do universo editorial evangélico, ${ }^{6}$ consistem em livros e textos brasileiros que abordam diretamente a homossexualidade: cerca de dez títulos da autoria de pastores e líderes religiosos, em sua maior parte atuantes em trabalhos pastorais com homossexuais. Artigos recolhidos no âmbito da atuação do Movimento pela Sexualidade Sadia (Moses) completa o corpus do material examinado na primeira parte. A opção por priorizar esses textos deve-se ao lugar dessa iniciativa religiosa no campo evangélico: o Moses possui atuação "interdenominacional" e é atualmente um importante articulador de trabalhos pastorais direcionados a homossexuais. Criado em 1997, no Rio de Janeiro, promove aconselhamento, palestras e "capacitação" para a evangelização de homossexuais, além de divulgar em seu site (www.moses.org.br) endereços e contatos de diversas instituições e iniciativas religiosas com objetivos similares.

$\mathrm{Na}$ segunda parte utilizo um material distinto, apesar de fazer referências à literatura antes discutida. Examino a produção discursiva sobre cura da homossexualidade (quatro títulos estrangeiros) e sobre libertação (dois títulos estrangeiros e quatro nacionais), incluindo falas de líderes religiosos proferidas em cultos pentecostais. A incorporação de publicações de autores estrangeiros justifica-se por figurar como "leitura indis- pensável" para quem deseja obter cura da homossexualidade em certos contextos religiosos. Deixando o homossexualismo, por exemplo, de Bob Davies e Lori Rentzel, é indicado no site do Moses como o livro mais importante sobre homossexualidade. Autores como a médica cristã Rebecca Brown e a pastora brasileira Neuza Itioka, foramme apresentadas por diversos informantes como "especialistas" em batalha espiritual, referências importantes no meio evangélico no que se refere a técnicas de libertação. De um total de dez livros, seis são de autoria de pastores ou líderes religiosos que ministram ${ }^{7}$ libertação e quatro de autores que atuam em pastoral com homossexuais. ${ }^{8}$ Assim, a presente literatura é tomada como documento, com conteúdo programático utilizado em contextos rituais que envolvem práticas de libertação e cura. A relevância desta análise justifica-se também pela grande procura desses livros. ${ }^{9}$ A participação como visitante no âmbito do Congresso Profético Apostólico 2005, permitiu acesso a palestras sobre restauração sexual e também observação etnográfica em ritos dedicados ao tema. ${ }^{10}$

\section{Do construtivismo moral ao naturalismo do gênero}

Os artigos divulgados pelo site do Moses contemplam temas diferenciados como movimento homossexual, parceria civil entre homossexuais, abuso sexual, pornografia, pedofilia, prostituição, gênero, aborto, teologia gay e movimento feminista. O teor de sua abordagem confere uma forte ênfase à problematização do "estilo de vida homossexual". Assim, apesar de o Moses sinalizar para um objetivo mais amplo de "ajudar os que sofrem de desvios sexuais de quaisquer espécies", fica evidente a preocupação específica com a homossexualidade. Na abordagem de cada um dos temas, apresenta-se um julgamento moral sobre as práticas homossexuais. As referências ao estilo de vida gay são inúmeras e constantes mesmo em textos que tratam de temas mais gerais, como, por exemplo, igualdade sexual. O entrecruzamento entre natureza e gênero indica o entranhamento da sexualidade em uma ordem moral abrangente, cuja determinação é divina A epígrafe deste artigo é ilustrativa desse aspecto: "nem homem, nem mulher", 
o pecado homossexual é desafiar uma ordem do mundo instaurada por Deus. Nessa percepção, práticas sexuais entre homens ou entre mulheres contrariam uma determinação divina com relação aos gêneros e a sexualidade. A mensagem religiosa completa-se na afirmação de que o desejo homossexual é passível de mudança.

A proposta pastoral apresentada no contexto da literatura evangélica ${ }^{11}$ possui conteúdo similar: há uma forte preocupação em apontar a verdade bíblica sobre os fatos relacionados à homossexualidade. O livro O dia em que nasci de novo (1993), do pastor João Carlos Xavier, apresenta o testemunho do próprio autor - ex-homossexual e ex-travesti - com o objetivo de "comprovar o que Cristo faz na vida de alguém aparentemente irrecuperável".

O conjunto dos artigos e livros conta com certa homogeneidade tanto em sua estrutura como em seus conteúdos: apresentam discussões sobre a origem da homossexualidade, seguidas pela explanação da verdade da Bíblia, para comprovar a possibilidade de cura. Também apresentam uma caracterização negativa da homossexualidade, acentuando os aspectos de uma "vida pregressa" associada a um comportamento desordenado, imoral e que conduz ao sofrimento. Recorrentes "exemplos" de cura contrastam o momento anterior e posterior à conversão do "ex-homossexual", sinalizando para a necessidade de adequação ao modelo normativo para os gêneros. Nestas narrativas, o passado está associado a uma espécie de inversão do gênero, oposto ao presente "restaurado", quando o homossexual masculino, por exemplo, pode transformar o "pecado do homossexualismo" na "bênção da heterossexualidade" por meio do casamento e da constituição de uma "família de Deus". ${ }^{12}$

No material examinado, algumas afirmações sobre a homossexualidade são recorrentes: 1) trata-se de um comportamento aprendido; 2) de um problema espiritual; 3) é uma antinatureza. Tais conceitos sustentam um posicionamento mais geral dos evangélicos de que o homossexualismo não representa um atributo "natural" do sujeito. Subjacente à concepção de que estas práticas podem ser abandonadas pela restauração e cura, há a idéia de uma natureza heterossexual. Vejamos como essa retórica se constrói pelo exame de cada enunciado.

\section{Homossexualidade: comportamento aprendido?}

Um dos temas centrais desses textos referese à gênese da homossexualidade. Uma discussão acalorada acerca da origem do comportamento homossexual apresenta-se a partir do confronto de teorias advindas dos saberes da biomedicina - que sustentam uma visão genética determinista - com aqueles que afirmam a "construção" da homossexualidade. Grande parte dos autores examina e refuta teorias que consideram a existência de uma pré-disposição ou tendência inata à homossexualidade, para em seguida afirmar o primado das influências ambientais, sociais e psicológicas na conformação das identidades homossexuais.

Lísias Castilho, médico cristão, autor do livro Homossexualidade, discute o tema no capítulo intitulado "Perspectiva biológica" e sustenta o posicionamento de que os saberes científicos "são transitórios". Apesar de homens e mulheres serem diferentes "anatomicamente, hormonal e funcionalmente desde a concepção", as "diferenças entre homossexuais e heterossexuais do mesmo sexo nunca foram claramente demonstradas, nem na esfera mental, nem na física". Para o autor, diversos estudos de base científica teriam falhado em seu esforço de demonstrar "a transmissão genética de tendências homossexuais" (Castilho, 1990). Assim, apresenta uma apropriação seletiva de algumas teorias psicologizantes e define "como" uma pessoa se torna homossexual: "abuso sexual na infância", "dificuldade na relação das crianças com seus pais" e "relacionamento deficiente com o genitor do mesmo sexo" são alguns dos fatores que propiciariam o aparecimento dessa deficiência ou doença. Seu texto é ilustrativo: "Ousamos afirmar, tal como tantas autoridades no campo da Psicologia, que o homossexual é, antes de tudo, um doente e, como tal, passível de tratamento e cura" (Idem, p. 65).

O exame da retórica construída por este autor sinaliza uma visão recorrente acerca da "origem" da homossexualidade. Nessa literatura, o comportamento homossexual é aprendido por meio de experiências negativas. As idéias que Castilho defende caracterizam uma espécie de tônica geral dos textos, com pequenas variações, em torno dos "fatores" que influem na "conforma- 
ção" de uma identidade homossexual. Com efeito, os argumentos são contrários a uma visão essencialista da homossexualidade. O homossexual é portador de sintomas de uma psique enferma. Homossexuais são dados à depressão e ao suicídio, são instáveis, inseguros e imaturos. Enfatizase uma representação patologizada das práticas homossexuais, articulada em torno das concepções de vício, compulsão e transtornos mentais. Em outro plano discursivo, acentua-se que tais práticas são "hábitos profundamente arraigados" que, contudo, constituem um estado passível de alteração: "as pessoas não são homossexuais mas estão homossexuais" (Santolin, 2001, p. 28); "O problema, portanto, não é ser ou não homossexual, mas estar ou não estar homossexualizado" (Souza, 2004). A homossexualidade é vista, fundamentalmente, como resultante da socialização em famílias desestruturadas, nas quais a ausência de firmes modelos de masculino e feminino produziria uma espécie de identificação com o gênero errado. É recorrente nesse contexto o uso da expressão transtorno ou crise de identidade de gênero. Pais ausentes e mães dominadoras são personagens obrigatórios nos casos evocados como exemplos de homossexualidade masculina.

\section{Homossexualidade: problema espiritual?}

A noção de problema espiritual suscita uma caracterização da homossexualidade que se aproxima da idéia anterior, em defesa da possibilidade de "reversão", já que ambas imputam à homossexualidade certa externalidade ao indivíduo, isto é, não a consideram algo inato.

J. Cabral, no livro O amor às avessas: homossexualismo, trata dos aspectos espirituais que podem conduzir à homossexualidade. Sobretudo, a adesão a rituais e crenças não evangélicos "podem ser inspiradoras do comportamento homossexual", levando à promiscuidade e perversão: "Os casos de possessão demoníaca podem estar associados diretamente à atividade homossexual. Acredita-se, inclusive, que existem demônios cuja atividade específica é provocar esse tipo de distorção nos seres humanos, afastando-os dos ensinamentos de Deus" (Cabral, 1995, p. 22). João Carlos Xavier, com seu testemunho como ex-homossexual, atualmente pas- tor da Assembléia de Deus - casado com uma serva de Deus e pai de um filho - apresenta visão semelhante no livro O dia em que nasci de novo. Seu homossexualismo teria se desenvolvido na umbanda, quando legiões de demônios "atuaram em sua vida" e "tomando seu corpo", o despertaram para os desejos homossexuais. A narrativa de Xavier é pontuada por considerações sobre o caráter maligno dos impulsos homossexuais. Considerase que este pecado sexual é perpetrado por indivíduos que têm diabo no corpo ou que estão sob influência de pombas-gira e outros exus. Esses argumentos, de teor cosmológico, configuram uma percepção físico-moral da homossexualidade, na qual o pecado abre brechas na corporalidade. $\mathrm{O}$ demônio instila sensações, movimentos, contrações involuntárias. Voltaremos a este ponto adiante, no momento cabe enfatizar que a luta contra a homossexualidade enseja a participação ritual e processos de purificação na resolução de um problema espiritual.

Esses dois livros ilustram a tônica das idéias apresentadas no conjunto do material examinado. Práticas homossexuais são apreendidas em experiências negativas de abuso, trauma, violência e rejeição (versão psicológica); ou dizem respeito a uma complexa cadeia de significados cosmológicos que recorre à teologia da batalha espiritual ${ }^{13}$ ao considerar a atuação de demônios sobre a esfera da sexualidade dos indivíduos. Tive acesso a esse tipo discurso não apenas na literatura, mas vários informantes afirmaram que esta é uma concepção difundida em suas igrejas..$^{14}$ No ambiente religioso considera-se que "os demônios são sexualmente transmissíveis". Nesse sentido, o pecado do homossexualismo deve ser evitado porque permite a infestação por seres malignos (Natividade, 2005, 2003 a e b). Sob a ótica dessa perspectiva, os transtornos sociais e psicológicos que colaboram para o desenvolvimento do homossexualismo podem ser causados por influência espiritual. De qualquer modo, em ambos os casos, a homossexualidade é externa ao indivíduo: sentimentos ou desejos homossexuais não constituem atributos inatos ao sujeito mas se conformam a partir de uma constelação de fatores "sociais" ou "espirituais".

Ampliando o foco de visão para o universo religioso, este discurso contrasta, sobretudo, com o da Igreja Católica, que não nega a prática homos- 
sexual como sendo uma tendência. Os católicos consideram a possibilidade de a homossexualidade constituir uma expressão da natureza de alguns indivíduos, apesar da afirmação - em um plano ideal - da necessidade de contenção pelo celibato e cultivo do amor de Deus (Natividade e Oliveira, 2004). Com efeito, o estar homossexual evangélico adquire contornos mais precisos quando contrastado com a posição relativamente mais tolerante dos católicos. ${ }^{15}$

A adoção de um posicionamento construtivista por parte dos evangélicos deixa margem à possibilidade de gerenciamento dos corpos na produção de uma sexualidade dentro dos limites determinados pela doutrina. Afirmar que o impulso homossexual tem origem em fatores ambientais ou espirituais é justamente o que permite o controle das condutas sexuais pela promessa de reversão da homossexualidade. A concepção evangélica, assim, conforma-se como um construtivismo moral, que em outro plano discursivo recorre a argumentos naturalistas em sua definição do gênero.

\section{Homossexualidade: antinatureza?}

O material examinado confere maior ênfase ao discurso que considera a homossexualidade uma prática que se opõe à natureza, o que aponta duas maneiras distintas de formulação. A primeira discute o uso natural dos corpos; a segunda enfoca especialmente a esfera do gênero. Argumentos "naturalistas" são utilizados tanto na caracterização de um uso sadio e apropriado do corpo, como na proposta de manutenção dos papéis de gênero tradicionais e complementares. Pode-se afirmar que certo essencialismo é re-introduzido no discurso evangélico ao caracterizar os modelos de homem e mulher conferidos por Deus. Proponho uma discussão a esse respeito partindo de uma passagem do livro supracitado, Homossexualidade, do médico cristão Lisias Castilho, e de um fragmento da matéria intitulada "Aberração", veiculada no site do Moses. Respectivamente:

O homossexualismo humano carece de sentido biológico, contraria a destinação anatômica dos órgãos genitais e impede a procriação (Castilho, 1990, p. 64).
Por onde se introduz a comida para dentro do corpo: é pelo nariz ou pela boca? Por onde se introduzem as imagens para dentro do corpo: é pela boca ou pelos olhos? Por onde se introduz o perfume para dentro do corpo: é pelo ouvido ou pelo nariz? Por onde se introduz o esperma para que se realize o ato de amor e se perpetue a espécie humana: é pela boca (sexo oral)? É pelo ânus (sexo anal)? É pela vagina (sexo natural)? [...] O homossexualismo é o abandono do modo natural por outro contrário à natureza (Revista Ultimato, 1986).

Essas passagens indicam a preocupação com um destino "natural" que restringiria os modos de uso do corpo. O tema central é voltado à definição dos limites para o prazer humano. Define-se o lícito e o ilícito para o sexo a partir de uma equação em que um comportamento normal e sadio é aquele que se orienta pelas determinações de Deus, que estariam expressas no texto bíblico. As sexualidades não-heterossexuais são, portanto, contrárias à Palavra e, nesse sentido, uma "anormalidade", "aberração" e comportamento que "irrita a Deus". Um princípio estrutural hierárquico apresenta-se, ressaltando que há "um lugar para cada coisa": o pênis, que produz esperma, não foi criado por Deus para o prazer individual (fora do casamento cristão), mas para a reprodução da espécie humana, para ser depositado em um vaso natural (a vagina), também criado por Deus. Transgredir essa ordem é abandonar um modo natural de vida. As práticas homossexuais, como afirma Castilho, "carecem de sentido biológico" e "contrariam a destinação anatômica" dos órgãos genitais. A família é considerada a expressão máxima de Deus na Terra, e a reprodução com a finalidade de constituir a família de Deus é o princípio defendido. Subjacente a idéia de que a sexualidade deve se pautar nas regras bíblicas está o suposto, mais ou menos velado, de que o 'bom' sexo é somente aquele que ocorre no interior do casamento cristão.

Desse modo, a associação entre reprodução e práticas sexuais é um recurso recorrente na definição do que é um modo natural e sadio de exercício da sexualidade. Afinal, "a união civil de um homem e uma mulher leva normalmente aos bebês, ao passo que a união sexual entre dois indivíduos do mesmo sexo leva normalmente a doen- 
ças" (Severo, 2003, p. 3). Está esboçada aí a construção da imagem da homossexualidade como uma prática que oferece perigo e ameaça à sociedade pela transmissão de doenças.

A carga moral presente nos argumentos desenvolvidos em torno do enunciado da antinatureza postula que a homossexualidade é "impureza", comportamento que contamina e contagia, de forma que tratar o homossexualismo - levar conversão a esta população - é produzir saúde social. É com este olhar que Júlio Severo, autor do livro O movimento bomossexual, examina os contatos homossexuais:

As típicas práticas sexuais dos homossexuais são histórias de terror: eles trocam saliva, fezes, sêmen e sangue com dezenas de homens por ano. Eles bebem urina, ingerem fezes e experimentam trauma retal regularmente. Muitas vezes, nesses encontros, os participantes se encontram bêbados, drogados ou em ambientes de orgia (1998, pp. 67-68).

O uso do corpo nos contatos sexuais homoeróticos é tratado como um desejo equivocado do homem de fazer um uso imoral (e antinatural) de si, que apresenta "graves conseqüências sociais". Para Severo, as "práticas sexuais dos homens homossexuais, envolvendo copulação oral após a sodomia retal assim como a contaminação dos dedos e das mãos durante os atos homossexuais, estão fazendo espalhar uma variedade de parasitas, bactérias e vírus pela sociedade" (Idem, p. 69). A imagem mais recorrente da articulação entre homossexualidade-impureza-contágio diz respeito à propagação da Aids, embora esta não seja a única doença sexualmente transmissível que os homossexuais "vivem a espalhar". Assim, práticas homossexuais culminam no castigo de Deus.

A dicotomia natureza versus antinatureza é, portanto, fortemente marcada - a partir dela se estruturam outras oposições: salvação-inferno, pureza-impureza, vida-morte, casamento-solidão, proteção-vulnerabilidade, felicidade-destruição, santificação-pecado. A homossexualidade, como prática antinatural, está sempre posicionada no pólo negativo, o que corrobora para a formação de uma imagem negativa em torno dela.
Seguindo essa lógica, Júlio Severo analisa a homossexualidade em diversos textos. Em As ilusões do movimento gay e O movimento homossexual, o autor aponta as "graves conseqüências sociais do homossexualismo". Para ele, os homossexuais são pedófilos, abusadores, tendem ao crime, ao excesso sexual, são dados à promiscuidade e, sobretudo, espalham doenças. Vale lembrar de que se trata da homossexualidade masculina, promíscua, irresponsável, que ameaça a família e propaga doenças. Em suma, expressão de uma sexualidade desordenada e excessiva, que tem como fim a morte. A homossexualidade feminina é citada com menor freqüência. Claudionor Corrêa de Andrade, ministro do evangelho da Assembléia de Deus, recorre a argumentos semelhantes no livro Há esperança para os homossexuais!. Ainda que este autor considere a homossexualidade feminina também um pecado, sua problematização focaliza sobretudo as relações masculinas. Com base em casos exemplares de dois homossexuais famosos (o ator norte-americano Rock Hudson e o escritor inglês Oscar Wilde), Andrade reflete sobre o trágico fim reservado a todo homossexual: Aids, solidão, morte e suicídio. Rock Hudson, morto vítima da Aids em 1986, "homossexual assumido e habituado às mais desenfreadas orgias, tornou-se vítima de sua própria depravação". Já Oscar Wilde, para o autor, é um exemplo da forma como o pecado "acelera a degeneração do ser humano"; "sua patética história é a inexorável redução de um homem a um zero humano", é a prova de que "tudo aquilo que o homem semear, isto ceifará" (Andrade, 1987).

Vale ressaltar que, ainda que os textos se refiram à homossexualidade de homens e mulheres em um plano ideal, há um descompasso na ênfase concedida a essas práticas. ${ }^{16}$ Severo afirma que "é muito mais fácil os homens se tornarem homossexuais, e isso em grande número, antes de as mulheres se tornarem lésbicas" (2004, p. 29). A conversão é, sobretudo, voltada à recuperação de homossexuais masculinos de uma vida pregressa de excessos, reconduzindo o indivíduo aos valores da família, do casamento e da religião.

Ao enunciado da antinatureza deverá ser apresentado a sua contrapartida. Se os homossexuais praticam sexo de modo não natural, então é verdadeiro que homens e mulheres (homosse- 
xuais) nascem heterossexuais, por determinação de seu sexo biológico:

Quando você foi gerado o seu sexo também foi determinado. [...] Você nasceu com seu sexo definido: possui órgãos sexuais definidos, normais e sadios. Os pêlos que cobrem seu corpo e o tom de sua voz. Também a estrutura física, o pélvis, os testículos, os ombros largos e a musculatura. Isso é uma confirmação que se impõe à sua situação [homossexual] (Feitosa, 1979, pp. 10-11).

A mensagem religiosa (naturalista) indica a heterossexualidade como "norma natural" desafiada pelos homossexuais. A psicóloga cristã Rozangela Alves Justino revela sua perspectiva naturalista no texto Da homossexualidade à heterossexualidade. ${ }^{17}$ Para a autora, haveria uma inclinação natural para a heterossexualidade passível de ser redescoberta pelo recurso a terapias:

Os clientes do GA [Grupo de Amigos] ${ }^{18}$ vêm com uma "máscara" de homossexual, procuram o GA para que sejam ajudados a tirá-la e pedem para confirmá-los como heterossexuais. No fundo sabem que a sua inclinação é para a heterossexualidade, mas por alguns motivos desempenharam o papel homossexual (1997, p. 30).

A homossexualidade é, assim, uma máscara, sob a qual jaz uma natureza heterossexual que pode e deve ser revelada, uma inclinação condizente com o sexo biológico. Se, em certo plano "Deus criou os homens com potencial para a homo ou para a heterossexualidade", em outro, Deus "determinou a heterossexualidade". Os argumentos naturalistas aqui expressos só fazem reforçar a hierarquia dos gêneros, posto que vincula fortemente o sexo biológico ao masculino e feminino. Trata-se de um naturalismo que adquire feições próprias, ou seja, um essencialismo moldado culturalmente pela religião, subsumido às concepções cosmológicas e doutrinárias. A natureza de que se fala é "natureza divina".

\section{A cura da homossexualidade em discurso}

Até o momento procurei caracterizar alguns princípios gerais que norteiam as práticas pastorais com relação à homossexualidade. Da postura "construtivista" ao naturalismo englobante das definições de gênero, são apresentadas concepções sobre a homossexualidade que permitem afirmar a possibilidade de mudança de orientação sexual. Meu intento nessa segunda parte do artigo é refletir sobre a noção de cura da homossexualidade Analiso o fenômeno, à luz de referencial teórico, dialogando com autores contemporâneos no campo das ciências sociais. Em seguida, focalizo as técnicas pastorais que propõem a cura pela via da experiência religiosa e examino noções empregadas como restauração sexual, cura das memórias e libertação.

O trabalho de Delma Pessanha Neves (1984), sobre comunidades da Assembléia de Deus, aponta uma perspectiva analítica relevante. De acordo com a autora, fenômenos de cura milagrosa, em um sentido genérico, reportam à necessidade de ordenar, submeter o indivíduo divergente ou sem fé às regras vigentes entre os crentes. O ideal de cura enfatiza a necessidade de adequação do indivíduo às normas e às prescrições religiosas, visto que o adoecimento e os infortúnios, de uma forma geral, remetem ao apartamento de Deus e à submissão aos prazeres carnais. Fenômenos de cura espiritual podem ser mais bem entendidos se inseridos no contexto de "atos ritualizados, que expressam a relação dos homens com o mundo por eles sobrenaturalizado ou com os poderes que atribuem às divindades" (Neves, 1984, p. 5). Com efeito, a noção de cura milagrosa pressupõe classificações relativas à doença e à saúde (felicidade e infortúnio), inseridas em um quadro referencial cosmológico e doutrinário.

Partindo dessa visão, o que seria passível de cura estaria situado em um conjunto muito amplo de fenômenos, que abarcam desde problemas orgânicos até desavenças familiares, desemprego, vícios de qualquer ordem, assim como os possíveis desvios na esfera da sexualidade (adultério, homossexualismo etc.). Nesse sentido, a cura de uma doença, a obtenção de um trabalho e a organização da vida familiar - tudo o que diz respeito à ordem idealizada na perspectiva doutrinária - são signos da condição de escolhido de Deus e protegido pelo Espírito Santo (Neves, 1984). O pecado é associado ao castigo, à degeneração humana, em oposição à onipotência de Deus, à graça, ao mere- 
cimento e ao poder mediador do Espírito Santo, que "naturalmente" os convertidos conseguem obter. Configuram-se, assim, percepções de doença e saúde que articulam o físico e o moral.

A análise da socióloga Cecília Mariz (1994) sobre a recuperação do alcoolismo entre os pentecostais de camadas populares no Rio de Janeiro traz novos elementos para reflexão. Para ela, o processo de conversão religiosa inclui certos modos de interiorização, ou seja, é a partir da adesão religiosa que o indivíduo se torna reflexivo e pode obter a libertação de "problemas" como o alcoolismo. Mariz ressalta que é na tensão entre liberdade e determinação que se produz a pessoa liberta no contexto de crenças evangélicas pentecostalizadas:" "o conceito de liberdade pentecostal assim se reporta a uma submissão a Deus, ou seja, a sua regra e a seu plano" (1994, p. 207). No sentido pentecostal, ser livre não significa seguir os impulsos e desejos individuais, mas, ao contrário, viver a Palavra, segundo a ética e as determinações de Deus. Trata-se de uma visão de mundo que articula magia - posto que é encantada - e ética, caracterizando uma forma de construção da pessoa que é, ao mesmo tempo, paradoxalmente individualista e holista: valoriza a transformação individual e incentiva a dependência de Deus e da comunidade religiosa. Nesse sentido, cura, libertação e regeneração pessoal aparecem como categorias intimamente vinculadas.

Clara Mafra (2002) também analisa a libertação evangélica, especialmente ao se deter sobre o sistema ritual da Igreja Universal do Reino de Deus, ressaltando o sentido performativo dessa forma religiosa que incentiva mudança do sentido ontológico. A constante referência ao demônio e a redescoberta de um mal personalizado reforçam o dualismo entre o bem e o mal e enfocam as performances que se realizam no culto religioso: a manifestação do demônio - e sua confissão acerca do mal que causa aos fiéis - fornece aos participantes um roteiro e um sentido para o sofrimento. Contudo, é também no contexto ritual que o crente aprende a derrotar o maligno. As orações poderosas, a corrente humana e a atuação do pastor, que exerce sua autoridade na expulsão dos demônios, tornam o culto uma espécie de aula de enfrentamento do mal. Desemprego, angústias e aflições são obra daquele que vive a atazanar os homens e a disputar com Deus a habitação do corpo do crente. Em contraste, viver em Cristo e tornar-se um templo do Espírito Santo resguarda das investidas do enganador, capacitando o crente a enfrentar as provações e as tentações no cotidiano. Para Mafra, cura e libertação são obtidas pela busca agonística de purificação ritual que envolve "queima ou amarração" do maligno, mas nunca sua derrota total. Assim, na "libertação ritual neopentecostal, o demônio nunca é vencido de uma vez por todas, mas sofre derrotas provisórias, uma após outra, no caso de batalhas bem sucedidas" (Idem, p. 219). Trata-se de um sistema religioso que objetiva, por meio de processos rituais de purificação, a transformação do indivíduo em um campo, uma superfície apta a ser habitada pela divindade (o Espírito Santo). Mafra, como outros autores, aponta a existência de determinadas formas de construção da subjetividade e da pessoa nesse contexto religioso, no qual as noções de cura, libertação e regeneração pessoal estão necessariamente presentes no aprendizado da teoria da pessoa dessa cosmologia.

A partir dessa discussão teórica, é possível distinguir três categorias no discurso evangélico que analisamos: cura, libertação e restauração sexual. A primeira é alcançada em um processo, referido como cura das memórias, o que indica a influência de um discurso psicologizante na prática religiosa. Já a libertação toma como ponto de partida a noção de possessão e enseja uma prática ritual na qual fiel e pastor encenam performances de expulsão do mal. A categoria restauração sexual circunscreve um ideal a ser atingido: a adequação a um modelo de gênero condizente com o ideal de homem e mulher de Deus. Parto dessa classificação mais geral para a análise dos discursos sobre a cura da homossexualidade.

\section{Restauração sexual: o retorno ao gênero natural}

Em primeiro lugar, cabe contextualizar o ideal em que se funda a concepção de restauração da sexualidade. Os discursos pastorais que privilegiam o uso dessa noção apresentam uma forte perspectiva normativa, ao conceber um único modelo para o exercício da sexualidade: somente são permitidas as práticas sexuais inseridas no 
casamento cristão. O que foge ao padrão é pecado e, portanto, desordem na sexualidade, comportamento que precisa de restauração, do "reparo" divino. Um impulso sexual natural (heterossexual), que foi pervertido em sua origem por experiências traumáticas e pela prática de certos pecados, é passível de ser restaurado pela comunhão com o Espírito Santo, em um processo que envolve cura das memórias, busca de santificação, disciplina e libertações. A extinção (ou mesmo a atenuação) dos desejos homossexuais, assim como a emergência de um impulso heterossexual natural, é almejada como possibilidade de conformidade ao destino concebido por Deus.

A retórica evangélica recorre a um naturalismo com certas especificidades: privilegia uma concepção de natureza divinamente concebida e ordenada. Todo esforço pela cura (em seu sentido ideal) envolverá necessariamente um retorno às determinações de Deus, no que tange à sexualidade humana. A noção de restauração sexual pressupõe também um ideal de gênero a ser perseguido pela via da experiência religiosa.

Alguns dos livros examinados conferem um lugar privilegiado ao gênero em suas definições sobre a cura da homossexualidade. Leanne Payne, autora de A cura do homossexual e Imagens partidas, apresenta casos de cura que envolvem a descoberta de uma masculinidade reprimida. Curarse é liberar uma energia masculina represada, desviada de seu curso e destino natural. Restaurar a sexualidade é receber cura na masculinidade e fazer emergir a energia natural do varão de Deus. Para outros autores, o impulso homossexual atenua-se com o tempo (ou mesmo se extingue), dando lugar ao impulso heterossexual (Davies e Rentzel, 1997).

A homossexualidade tratada por Payne como crise de identidade pela identificação com o gênero oposto implica um desenvolvimento sexual imaturo, que pode ser curado por orações. Sugere a "oração pela liberação do impulso heterossexual normal", com a invocação da presença do Espírito Santo, para o despertar da energia sexual dormente. O uso da metáfora compulsão canibalista define a origem de uma identidade homossexual, por um viés psicológico: desejos homossexuais indicam a necessidade de "buscar no outro" o que não é reconhecido em si. Nessa perspectiva, na restauração da sexualidade ocorre a recuperação dos atributos naturais de masculinidade pela eleição de certos modelos como ideais a serem alcançados. O discurso pastoral busca a adequação do corpo e da sexualidade a um modelo de gênero hierárquico:

[...] ungi sua testa com óleo, pedi que nosso Senhor entrasse, curasse e colocasse no curso normal os desejos e impulsos sexuais normais do José de dezessete anos. [...] Após esta oração, eu o conduzi para, consciente e deliberadamente, mudar seus trejeitos, sugerindo que ele selecionasse o homem mais masculino que pudesse imaginar como seu modelo - alguém a quem ele admirava como cristão, como líder, marido e pai e isso ele prometeu fazer (Payne, 2001, p. 80).

O ideal de gênero considera atributos naturalmente masculinos a iniciativa, a confiança, a agressividade e a virilidade, reforçando uma concepção assimétrica dos papéis de gênero, o que pode ser ilustrado pela narrativa de João Carlos Xavier (1993). Mudar trejeitos, consertar a voz, alterar a maneira de vestir-se, modificar o linguajar, ${ }^{20}$ abandonar tudo aquilo que fazia parte de sua vida homossexual, foram atitudes que tomou para restaurar sua sexualidade:

Procurava me adaptar à maneira de vestir dos irmãos espirituais consagrados. Orei muito a Deus pedindo que tirasse de mim todos os trejeitos que fazia com as mãos e expressões corporais efeminados. Pedi também ao Senhor que modificasse minha vOz, pois falava esquisito devido ao convívio com os homossexuais. [...] Em casa desfiz-me de tudo o que me fazia lembrar o passado: fotografias vestido de mulher, e objetos pessoais; quadros e discos de Rock foram queimados; as bebidas alcoólicas não poucas, despejei todas no vaso sanitário cantando hinos com muita alegria (Xavier, 1993, pp. 132-133).

Sua mudança para uma identidade de $e x$ homossexual foi precedida pelas orações, pelo Batismo do Espírito Santo, pela experiência de adequação de sua vontade à de Deus e pelas libertações. Do ponto de vista das perspectivas pastorais aqui apresentadas, esses são os passos fundamentais à "transformação", que apresento a seguir. 


\section{Cura das memórias}

A literatura religiosa concebe a cura das memórias como etapa fundamental na restauração da sexualidade, partindo do pressuposto de que a homossexualidade, assim como outros desvios sexuais, se encontra firmemente "arraigada" na mente do indivíduo, sob a forma de emoções doentes, traumas e vicios. Para atingir a cura das memórias, é preciso buscar a raiz do problema, localizando as lembranças para situar quando e onde se deu o desvio de um curso normal da sexualidade. Do ponto de vista cosmológico, afirma-se que a prática de determinados pecados ${ }^{21}$ abre brechas no corpo do indivíduo, pelas quais os demônios atuam escravizando a mente e induzindo a novos pecados, como a homossexualidade. Em contrapartida, o discurso pastoral oferece a pacificação do indivíduo pelo Espírito Santo, como "saída" ao domínio de Satanás. O Espírito Santo é divindade que consola, trata, cura e apaga as lembranças. Os conselhos pastorais são: "livrar-se de padrões mentais negativos", "reprogramar a mente", "buscar renovação mental" e "substituir as informações erradas" (Emerich, 2004). A mensagem religiosa completa-se na seguinte proposição: deve-se "saturar o pensamento das coisas de Deus", com orações constantes, biblioterapia (decoração de versículos bíblicos), participação em atividades religiosas e cultivo do amor ao próximo. O discurso da cura das memórias enfatiza a necessidade de esvaziar o pensamento das imagens que não provêm de Deus, uma vez que a mente é o lugar privilegiado para as investidas de Satanás. O pastor Alcione Emerich defende "que o principal alvo do diabo é dominar a mente do homem, pois, assim fazendo-o, o terá por completo debaixo de seu controle, comandando sua mente, tem-se o controle do corpo, da língua, das vontades, das formas de relacionar-se socialmente, em suma, de tudo" (Emerich, 2004, p. 139). O controle do pensamento é um instrumento na verdadeira guerra espiritual.

Esse discurso apresenta um ideal de sujeito, dotado de autonomia, autocontrole e vontade. $\mathrm{O}$ indivíduo é convidado a arrepender-se, confessar seus pecados e renunciar ao erro. É no contexto de libertações ou de ministrações de cura que o fiel é conduzido ao auto-exame:
Uma confissão bem feita, com auxílio do ministrador, pode possibilitar a saída de todo o lixo emocional guardado durante anos. É esse lixo emocional que adoece a alma e o corpo, conforme eu já disse. Ele precisa ser expurgado. Mas, além disso, a ferida exposta precisa ser sarada (Idem, p. 170).

A confissão é o principal método para a cura, posto que sem ela não é possível se libertar. Trata-se de uma técnica de direção espiritual, que tem por objetivo a revelação do pecado (Foucault, 2002), na qual o indivíduo é incentivado a reviver o passado, buscando exaustivamente seus erros. Ritos de confissão são produtores de "verdade", procedimentos que buscam a conformação do indivíduo às normas da instituição (Lima, 1986). ${ }^{22}$ É importante ressaltar, contudo, o caráter criativo da confissão pentecostal: o ato de proferir os pecados quebra maldições, interrompe a atuação maligna, expulsa demônios e permite a intervenção do Espírito Santo na pacificação da mente e na cura das emoções. A pacificação aparece estruturada sob a forma do perdão recebido (por Deus) e do perdão concedido a "outros". Leanne Payne, que ministra cura da homossexualidade, afirma:

A necessidade principal, claro, é de cura da própria lembrança traumática. Nessa oração, a vítima perdoa àquele que pecou monstruosamente contra ela. Os efeitos deste pecado são lançados para longe, para que a pessoa não esteja mais presa, marcada ou ferida por eles. Então, conforme o Espírito Santo conduziu, convidamos o Senhor a entrar na memória, purificando e curando

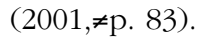

Para a autora, a libertação da mente e a cura do homossexualismo são obtidas com a identificação da raiz do problema (o trauma original, que instituiu o comportamento). A partir de então, o perdão é concedido e dá-se a cura das mágoas pelo Espírito Santo. O indivíduo, purificado de emoções que o contaminavam, poderá desenvolver novos comportamentos em relação à sexualidade.

A pastora Neuza Itioka (2005), ao ministrar a cura dos pecados sexuais (que inclui a prática da homossexualidade, assim como todo o sexo fora do casamento cristão: "pornografia", "masturba- 
ção", "adultério") também ressalta a relevância da confissão dos pecados para a restauração sexual. Sua técnica conjuga auto-exame, confissão e renúncia do pecado. A obrigação da exaustividade é expressa na ressalva de que o esquecimento de pecados na confissão impede a cura. Assim, toda a biografia do sujeito deve passar pelo crivo da memória: o passado deve ser pesquisado, analisado, examinado, perscrutado, confessado e renunciado. Os fatos e os eventos que compõem a vida anterior da pessoa são constantemente ressignificados como pecado e erro. Mas não apenas o passado individual deve ser objeto de confissão, também as relações familiares e os pecados de pessoas da família (da mesma geração ou de outras) precisam ser revelados e submetidos ao perdão de Deus. Temos aqui certa concepção de pecados compartilhados, que enfatiza a necessidade de libertação não apenas do indivíduo, mas também da família, a fim de que esta venha a se constituir como família de Deus. A biografia do sujeito aparece inserida dentro de um circuito do mal que, pela libertação, pode ser interrompido. Essa interrupção exige o "quebrantamento" do indivíduo: é a submissão a Deus que liberta. Itioka enfatiza a importância de quebrantar-se, de humilhar-se diante do Senhor para obter cura e libertação. ${ }^{23}$

O discurso sobre a cura das memórias indica procedimentos e métodos de produção do sujeito, com a finalidade de desenvolvimento de uma ética sexual, do cultivo de si pelo autoexame e pelo exercício da disciplina. O que está em foco é a busca do exercício da vontade:

Por muito tempo o indivíduo desenvolveu um padrão de submissão em que foi reduzida e nulificada sua mente e sua vontade. [...] A imagem de Deus que consiste em desenvolver a vontade e a liberdade humana tem que ser redescoberta, como um dom de Deus, e a pessoa deve perceber a importância e a sublimidade da vontade humana aos olhos de Deus e aos olhos dos outros seres humanos (Itioka, 1993, p. 225).

Esse conjunto de valores assemelha-se àquele investigado por Tânia Salém (1992) na literatura de auto-ajuda. Individualidade, vontade e posse de si constituem o núcleo de preocupações a partir do qual são propostas determinadas téc- nicas e conselhos. Vale lembrar que no universo pesquisado o termo libertação tem um sentido bastante particular: libertar-se é recuperar o controle de si, é ver-se livre dos constrangimentos infringidos pelas potências do mal. Com efeito, há semelhanças entre o discurso religioso e a literatura de auto-ajuda nesse sentido - "Livre de quaisquer constrangimentos e de determinações externas, o 'indivíduo natural' encontra-se imerso no reino do livre-arbítrio, da escolha, da vontade e da consciência" (Salém, 1992, p. 11) - mas a proposta pastoral difere pela especificidade de suas técnicas, englobadas pela perspectiva religiosa. Não se trata, portanto, da produção do indivíduo autônomo moderno, mas de uma autonomia conquistada pela submissão a Deus, que é quem protege, separa, aparta do mal (Mariz, 1994). Contudo, o controle de si também pode ser obtido pela transformação do sujeito em templo do Espírito Santo - ser cheio, pleno da divindade.

\section{Do corpo carne ao corpo templo}

A análise empreendida até aqui aponta para a dimensão da corporalidade ao fazer uso das noçôes de corpo carne e corpo templo, idéias presentes com maior ênfase na literatura sobre batalha espiritual, mas também em livros (e contextos rituais) que focalizam a cura da homossexualidade. A imagem do corpo carne indica a necessidade de renascimento, que compõe todo processo de conversão. O discurso pastoral, fundado em princípios cosmológicos, enfatiza a necessidade da morte do "eu" (antigo), para o posterior despontar de uma nova criatura. As metáforas estar pleno, cheio do Espirito Santo, encher-se de Deus expressam um discurso cosmológico que concebe um "eu" sagrado, de corpo, mente e espírito curados e libertos. O sujeito de vontade fraca, que cedia aos ditames da carne pela prática do pecado, pode se tornar o indivíduo que renuncia, resiste e é senhor de seus impulsos, portador de uma ética construída pela busca da restauração sexual. Em concordância com Foucault (2004), estamos diante de tecnologias de si que visam a instaurar o autocontrole, de forma similar ao ideal celibatário dos primórdios do cristianismo. A discussão em torno do desejo e do impulso homossexual apresenta o exercício da von- 
tade como problema axial: buscar a cura da homossexualidade; libertação ou restauração sexual significam exercer uma ética sexual baseada nos princípios da renúncia e da contenção, na reflexividade diante dos desejos.

De acordo com Carrara (2000), há duas vertentes no pensamento cristão que constroem formulações acerca do desejo sexual a partir de distintas concepções da pessoa. A primeira é caracterizada pela ênfase na abstinência sexual e no ideal do celibato, buscando a santificação pela conversão, pelo batismo e pelo fervor da fé. Trata-se de um ideal "autonomista", que valoriza o autocontrole e o domínio de si em relação aos impulsos da carne. Esta concepção caracterizou o cristianismo em seus primórdios (Foucault, 2004; Duarte e Giumbelli, 1995; Brown, 1990), tendo sido apropriada e reinventada em sua versão puritana com a emergência do protestantismo e seu ideal ascético (Weber, 2001). Uma outra formulação encontra-se em Santo Agostinho, quando retoma o tema do pecado original. O pensamento agostiniano apresenta uma teologia que tematiza negativamente a sexualidade, realçando a carnalidade bumana, fruto da queda e da prática do pecado original. Assim, cada fiel carrega a marca indelével do pecado, posto que os desejos da carne possuem uma base incontrolável e demoníaca.

No universo evangélico, pentecostalizado, ambas as concepções coexistem: a idéia da passagem do corpo carne (anterior à conversão, à cura e à libertação) ao corpo templo (cultivado pelo exercício da ética doutrinária) indica a existência de um ideal de transmutação da essência da pessoa. É por meio desse pendor ao pecado que são exercidas práticas antinaturais, abrindo brechas ao maligno (Rebecca Brown, 2000; Itioka, 1993). Trata-se de um corpo transpassado pelos poderes malignos, infestado por legiões de demônios, contaminado, um corpo habitat, receptáculo dos diabos, portador de desejos equivocados em relação à verdade e à natureza divina

A cura das memórias e a libertação fazem parte do processo de limpeza ritual e busca de santificação. Adequar a vontade do fiel à vontade de Deus é o princípio que garante o preenchimento, a habitação pelo Espírito de Deus. Estar pleno é fundir-se à divindade ou tornar-se Ela. Deste modo, do discurso sobre cura e libertação desponta um "eu" concebido na dualidade: quan- do cheio, indivíduo autônomo; quando vazio, indivíduo sem vontade. Inicialmente, tem-se a concepção do corpo como carne corrompida pelo pecado, possuída por demônios, que, posteriormente, é transfigurada pelo preenchimento, tornando-se templo do Espírito Santo. O discurso sobre libertação e cura enfatiza a transmutação da carne em natureza divina, que devolve a autonomia e vontade ao sujeito. É nesse sentido que ceder aos pendores da carne e do pecado é permanecer cativo sob o domínio de Satanás. Em contrapartida, processos de limpeza ritual que incidem sobre o corpo - transformando-o em templo da divindade - devolvem a vontade e autonomia ao sujeito.

\section{Considerações finais}

A análise mostrou como evangélicos proferem um discurso que afirma a exterioridade da homossexualidade, rejeitando concepções deterministas e afirmando a possibilidade de reversão por meio da conversão. As acusações morais subjacentes ao discurso sobre a cura revelam um pânico moral insuflado pelo cultivo de uma imagem negativa. Homossexuais são vistos como "promíscuos", "pedófilos" e sujeitos que "espalham doenças", portanto indivíduos perigosos à coletividade. Também foi possível perceber uma apropriação de noções oriundas de outros saberes institucionalizados, a partir da veiculação de imagens da homossexualidade como "doença", "vício", "perversão" ou "degeneração". Carrara e Vianna (2004) chamam a atenção no sentido de que essas imagens se tratam de representações da homossexualidade constituintes dos saberes biomédicos do início do século passado. A problematização acerca da "gênese" da homossexualidade - atrelada a práticas visando a uma reestruturação das condutas sexuais - revelou uma preocupação exaustiva com as sexualidades periféricas. Seja como for, a homossexualidade não se localiza fundamentalmente no orgânico, mas nas memórias e nas experiências vividas, o que sugere a interpenetração entre psicologia e religião (Semán, 2000). A noção de cura e o ideal de restauração sexual buscam construir um sujeito reflexivo e implantar uma ética sexual. O impul- 
so homossexual pode emergir sob a forma de tentações e provações, mas é preciso uma verdadeira guerra espiritual pelo controle e posse de si. O ideal da transformação do sujeito em um templo do Espírito Santo busca reforçar essa dimensão ética. Afinal, um templo é sagrado e deve ser resguardado.

As considerações aqui empreendidas não procuram oferecer uma visão homogênea desse campo religioso. O material examinado aponta para a perspectiva de atuação de determinados grupos religiosos, principalmente daqueles ligados a trabalhos pastorais que buscam o gerenciamento da sexualidade.

Na pesquisa mais ampla que venho realizando, ao coletar entrevistas com homossexuais evangélicos, descobri que alguns indivíduos procuram ajuda na igreja para questões da sexualidade, o que indica o recurso a iniciativas religiosas que oferecerem cura. Sob a forma de libertações individuais (da qual podem participar pastor, psicólogo cristão e fiel) ou de aconselhamentos pastorais, apresenta-se uma perspectiva religiosa que dialoga com conceitos e práticas psicológicas. Tal articulação entre religião e psicologia deverá ser objeto de reflexão em outros trabalhos. Limito-me no momento a sugerir que, do discurso sobre a cura da homossexualidade - que enfatiza a importância da cura das memórias, procedimentos de procura interior e valorização do "eu" - emerge uma prática pastoral que articula elementos da tradição religiosa e certos modos de subjetivação modernos. Alimenta-se, assim, o diálogo entre visões religiosas do mundo e visões individualizadas (Semán, 2000, p. 219). Cabe enfatizar a entrada, neste campo, de certos atores sociais, como psicólogos, psicanalistas ou mesmo médicos cristãos, que conjugam identidade religiosa e profissional e que causam impacto no âmbito religioso.

Do ponto de vista da experiência dos sujeitos, a abordagem da questão é muito delicada e envolve a análise das passagens e das mediações sociais nas trajetórias biográficas, uma vez que a experiência religiosa é constituída por três dimensões distintas: identidade ou pertencimento; adesão, experiência ou crença; e, em um terceiro plano, o ethos religioso, como disposição ética ou comportamental (Duarte, 2005). Ressalto que as concepções examinadas sinalizam para a tensão entre modernidade e tradição em contextos religiosos, em que princípios de mudança e permanência se relacionam com cosmologia e doutrina. O paradoxo é profícuo para pensar como essas tensões são atualizadas em contextos religiosos por meio da oposição entre exercício da sexualidade e vida religiosa. No discurso sobre cura e libertação, tecnologias que visam ao cultivo de si e à racionalização dos controles corporais convivem com a manutenção da assimetria entre os gêneros.

\section{BIBLIOGRAFIA}

ANDRADE, Claudionor Corrêa. (1987), Há esperança para os homossexuais! Rio de Janeiro, Casa Publicadora das Assembléias de Deus.

BERGNER, Mário. (2000), Amor restaurado: esperança e cura para o homossexual. São Paulo, Sepal.

BROWN, Peter. (1990), Corpo e sociedade: o bomem, a mulher e a renúncia sexual no início do cristianismo. Tradução de Vera Ribeiro. Rio de Janeiro, Jorge Zahar.

BROWN, Rebecca. (1998), Vaso para a bonra. Tradução de César de Azevedo Gil. 3 ed. Rio de Janeiro, Danprewan Editora e Comunicações Evangélicas.

(2000), Ele veio para libertar os cativos. 4 ed. Belo Horizonte, Editorial Dynamus.

CABRAL, J. (1995), O amor às avessas: homossexualismo. Rio de Janeiro, Gráfica Universal Ltda.

CARRARA, Sérgio. (2000), "Utopias sexuais modernas: uma experiência religiosa Americana”. Etnográfica, 4 (2): 355-368.

CARRARA, Sérgio \& VIANNA, Adriana R. B. (2004), "As vítimas do desejo: os tribunais cariocas e a homossexualidade nos anos 1980", in S. Carrara et al. (orgs.), Sexualidade e saberes: convenções e fronteiras, Rio de Janeiro, Garamond.

CASTILHO, Lísias Nogueira. (1990), Homossexualidade. 2 ed. São Paulo, ABU.

DALLAS, Joe. (1998), A operação do erro: con- 
frontando o movimento gay cristão. São Paulo, Editora Cultura Cristã.

DAVIES, Bob \& RENTZEL, Lori. (1997), Deixando o homossexualismo: uma nova liberdade para homens e mulheres. Tradução de Yolanda M. Krievin. São Paulo, Mundo Cristão.

DUARTE, Luiz Fernando Dias. (2003), "Ethos privado e justificação religiosa: negociações da reprodução na sociedade brasileira". Comunicação apresentada no "Seminário Religião e Sexualidade: Convicções e Responsabilidades", Iser/Clam-IMS-Uerj, Rio de Janeiro.

DUARTE, Luiz Fernando Dias \& GIUMBELLI, Emerson A. (1995), "As concepções cristã e moderna de pessoa: paradoxos de uma continuidade". Anuário Antropológico, 93: 77-111.

ELIAS, Norbert. (1994), O processo civilizador. Tradução de Ruy Jugman. 2 ed. Rio de Janeiro, Jorge Zahar, vol. 1.

EMERICH, Alcione. (2002), Saindo do cativeiro: como ajudar pessoas a se libertarem de alianças do passado. 3 ed. Rio de Janeiro, Danprewan.

(2004), Físico, psicológico ou espiritual? Qual a origem do seu problema? Rio de Janeiro, Danprewan.

FEITOSA, Reuel P. (1979), O avesso do amor. 3 ed. Belo Horizonte, Venda Nova.

FERNANDES, Rubem César et al. (1998), Novo nascimento: os evangélicos em casa, na Igreja e na política. Rio de Janeiro, Mauad.

FOUCAULT, Michel. (1997), História da sexualidade I: a vontade de saber. Tradução de Maria Thereza da Costa Albuquerque e J. A. Guilhon Albuquerque. 12 ed. Rio de Janeiro, Graal.

(2002), Os anormais: curso no Collège de France (1974-1975). Tradução de Eduardo Brandão. São Paulo, Martins Fontes. (2004), "Sexualidade e solidão", in M.
B. da Motta (org.), Ética, sexualidade, política, tradução de F. Durand-Bogaert, Rio de Janeiro, Forense Universitária.

FRY, Peter. (1982), Para inglês ver: identidade e política na cultura brasileira. Rio de Janeiro, Zahar Editores.

GEERTZ, Clifford. (1989), A interpretação das culturas. Rio de Janeiro, LTC Editora.

HEILBORN, Maria Luiza. (1999), "Construção de si, gênero e sexualidade", in M. L. Heilborn (org.), Sexualidade: o olhar das ciências sociais, Rio de Janeiro, Jorge Zahar.

ITIOKA, Neuza. (1993), Os deuses da umbanda: o baixo espiritismo, implicações teológicas. São Paulo, ABU.

(2003), Cristo nos resgata de toda maldição. 2 ed. São Paulo, Sepal.

(2005), "Restauração sexual". Palestra. Congresso Profético Apostólico 2005: Um novo Rio para o Brasil, Rio de Janeiro (mimeo.)

JUSTINO, Rozangela Alves. (1997), Da homossexualidade à heterossexualidade: há possibilidade de resgate da heterossexualidade. Rio de Janeiro, Grupo de Amigos (GA). (mimeo.).

LIMA, Lana Lage da Gama. (1986), "Aprisionando o desejo: confissão e sexualidade, in $\mathrm{R}$. Vainfas (org.), História e sexualidade no Brasil, Rio de Janeiro, Graal.

MACHADO, M. D. C. (1996), Carismáticos e pentecostais: adesão religiosa na esfera familiar. Campinas, Autores Associados/ Anpocs.

MACHADO, M.D.C. \& MARIZ, Cecília. (1996), "Pentecostalismo e a redefinição do feminino". Religião e Sociedade, 17 (1-2): 140-159.

MAFRA, Clara. (1998), "Gênero e estilo eclesial entre os evangélicos" in R. C. Fernandes et al. (orgs.), Novo nascimento: os evangélicos em casa, na Igreja e na política, Rio de Janeiro, Mauad.

(2001), Os evangélicos. Rio de Janeiro, Jorge Zahar (col. Descobrindo o Brasil). 
(2002), Na posse da palavra: religião, conversão e liberdade pessoal em dois contextos nacionais. Lisboa, Imprensa de Ciências Sociais.

MARIZ, Cecília Loreto. (1994), "Libertação e ética: uma análise do discurso de pentecostais que se recuperaram do alcoolismo", in A. Antoniazzi et al. (orgs.), Nem anjos, nem demônios: interpretações sociológicas do pentecostalismo, Petrópolis, Vozes.

(1999), "A teologia da batalha espiritual: uma revisão da bibliografia". Revista Brasileira de Informação Bibliográfica em Ciências Sociais, 47 (1): 33-48.

NATIVIDADE, Marcelo Tavares. (2003a), Carreiras homossexuais e pentecostalismo: análise de biografias. Dissertação de mestrado, Universidade do Estado do Rio de Janeiro, Instituto de Medicina Social (mimeo.).

(2003b), "Carreiras homossexuais no contexto do pentecostalismo: dilemas e soluções". Religião \& Sociedade, 23 (1): 132-152.

(2005), "Homossexualidade masculina e experiência religiosa pentecostal", in L. F. D. Duarte et al., Sexualidade, familia e ethos religioso, Rio de Janeiro, Garamond.

NATIVIDADE, Marcelo Tavares \& OLIVEIRA, Leandro de. (2004), "Algumas tendências recentes nos discursos evangélico e católico sobre a homossexualidade". Sexualidade, Gênero e Sociedade, ano XI (22): 1-5, dez.

NEVES, Delma Pessanha. (1984), As curas milagrosas e a idealização da ordem social. Niterói, UFF.

OLIVEIRA, Leandro de. (2004), "O gênero dos invertidos: representações das práticas homossexuais de homens e mulheres no nascimento da sexologia brasileira", in D. Lopes et al., Imagem \& diversidade sexual: estudos da bomocultura, São Paulo, Nojosa Edições.

PAYNE, Leanne. (1994), A cura do homossexual. Tradução de Dom Heriberto Hermes. Rio de Janeiro, Louva-a-deus.
(2001), Imagens partidas: restaurando a integridade pessoal por meio de oração. Tradução de Elisabeth Gomes. São Paulo, Sepal.

SALÉM, Tânia. (1992), "Manuais modernos de autoajuda: uma análise antropológica sobre a noção de pessoa e suas perturbações". Série Estudos em Saúde Coletiva, 7: 1-36.

SANTOLIN, João Luiz. (2001), Para Deus não há acepção: o que a Bíblia diz, qual a postura da igreja e como devem proceder os que querem deixar o homossexualismo. Rio de Janeiro, Moses (mimeo).

SEMÁN, Pablo. (2000), A fragmentação do cosmos: um estudo sobre as sensibilidades de fiéis pentecostais e católicos de um bairro da Grande Buenos Aires. Tese de doutorado, Universidade Federal do Rio Grande do Sul (mimeo.).

SEVERO, Júlio. (1998), O movimento homossexual: sua história, seus traumas e ações, seu impacto na sociedade, seu impacto na igreja. Belo Horizonde, Venda Nova/Betania.

(2003), "As ilusões do movimento gay". Disponível no site <http://www.cacp.org.br>. Acesso em 21 de outubro de 2004.

. (2004), "Entendido? Como assim? Será que os gays chamados entendidos entendem tudo mesmo?". Disponível no site $<$ http://www.moses.org.br>. Acesso em 18 de agosto de 2004.

SOUZA, Celso Milan. (2004), "Direitos dados pelo criador e direitos inventados pela criatura". Disponível no site <http://www.moses.org.br>. Acesso em 19 de agosto de 2004.

UlTiMATO. (1986), "Aberração". Disponível no site <http://www.moses.org.br>. Acesso em 20 de agosto de 2004.

XAVIER, João Carlos. (1993), O dia em que nasci de novo. Rio de Janeiro, Casa Publicadora das Assembléias de Deus (CPAD).

WEBER, Max. (2001), A ética protestante e o espirito do capitalismo. Tradução de M. Irene de Q. F. Szmrecsányi e Tamás J. M. K. 
Szmrecsányi. São Paulo, Pioneira Thomson Learning.

WEEKS, Jeffrey. (1999), "O corpo e a sexualidade", in G. L. Louro, O corpo educado: pedagogias da sexualidade, Belo Horizonte, Autêntica.

\section{Notas}

1 Refiro-me ao Projeto de Lei 717/2003, de autoria do deputado religioso Édino Fonseca, apresentado à Assembléia Legislativa do Estado do Rio de Janeiro em 27 de agosto de 2003. Apesar de ter recebido dois pareceres positivos durante o seu exame, foi rejeitado pela Alerj em 8/12/2004 por trinta votos contra seis favoráveis.

2 Esses grupos congregam membros de diferentes denominações evangélicas, representando um posicionamento relativamente consensual sobre o pecado da homossexualidade e as formas de cuidado pastoral que este comportamento enseja. Por isso, eles atuam em conjunto não apenas em aconselhamento, mas também na capacitação de religiosos para lidar com o "problema" em suas igrejas.

3 A reflexão aqui empreendida está inserida em uma pesquisa mais ampla que desenvolvo, como doutorando no Programa de Pós-Graduação em Sociologia e Antropologia do Instituto de Filosofia e Ciências Sociais (Universidade Federal do Rio de Janeiro). Tal pesquisa trata dos discursos sobre a homossexualidade e os processos de construção de si entre evangélicos moradores da cidade do Rio de Janeiro.

4 Iniciativas religiosas de comunidades da Assembléia de Deus, Igreja Metodista, Igreja Batista, Igreja Presbiteriana, Igreja Sara Nossa Terra aparecem no site do Moses, oferecendo aconselhamento e "ajuda" a homossexuais.

5 Neste cenário, uma perspectiva minoritária posiciona-se com a emergência de denominações protestantes, noticiadas pela mídia como igrejas que aceitam gays. No Rio de Janeiro, adotam esse discurso, a Igreja Presbiteriana Unida de Bethesda (Copacabana) e a Igreja da Comunidade Metropolitana (Centro). É possível pensar nessa tendência recente como constituindo um movimento gay cristão embrionário, cujas influências estariam na existência de uma vertente norte-americana que se formou a partir dos anos de 1970. Sobre esse aspecto, ver Dallas (1998). O autor evangélico busca analisar - sob uma visão bíblica - as transformações que ocorrem na igreja a partir das conquistas políticas dos homossexuais e da constituição desta vertente protestante, cujo principal expoente é a Metropolitan Community Church.

6 A pesquisa inicial dedicou-se à consulta dos catálogos on line de 37 editoras evangélicas e também de livrarias especializadas (no Rio de Janeiro, cerca de quinze endereços), além do acervo do Seminário Teológico Betel (Tijuca, RJ). Mapeou-se uma ampla bibliografia sobre temáticas relativas à sexualidade, ao gênero, à juventude e à homossexualidade. Essa etapa exploratória envolveu ainda o monitoramento dos conteúdos dos sites do Conselho de Psicólogos e Psiquiatras Cristãos, do Movimento pela Sexualidade Sadia, da Igreja Universal do Reino de Deus e outras iniciativas religiosas pertinentes.

7 Termo nativo que designa momentos rituais cuja função principal é expulsar demônios e propiciar cura espiritual.

8 Refiro-me aos norte-americanos Leanne Payne, Mário Bergner, Bob Davies e Lori Rentzel.

9 A cura do homossexual, da autoria de Leanne Payne, foi publicado pela primeira vez em 1993, com segunda edição em 1994. Enfocando o tema mais geral da libertação, Saindo do cativeiro, cujo autor é o pastor pentecostal Alcione Emerich, está em sua terceira edição após dois anos da primeira publicação em 2002. Outro exemplo do consumo desses livros é o título Vaso para a honra, da escritora evangélica norte-americana Rebecca Brow, publicado inicialmente em 1998 e tendo já sua terceira edição no ano de 2001.

10 O encontro ocorreu entre 19 e 22 de janeiro de 2005 e reuniu cerca de seis mil pessoas, contando com líderes religiosos e fiéis de diferentes igrejas evangélicas. Foi dedicado ao tema da batalha espiritual. A observação etnográfica do evento permitiu acesso a um material privilegiado, pois contou com a participação da ministra de libertação e escritora Neuza Itioka, que conduziu momentos rituais dedicados à restauração sexual dos fiéis. Um dos objetivos do rito consistia em libertar da homossexualidade, assim como de outros pecados sexuais como "masturbação", "infidelidade", "sexo antes do casamento". A pastora argumentou a necessidade de expandir o trabalho de libertação na sexualidade para outras regiões. Comentou que realizava um trabalho itinerante, visitando igrejas 
em diversos estados e regiões do país, propiciando momentos rituais como aquele. Tal tarefa se fazia urgente, visto que a maior parte dos brasileiros "tinha problema na área da sexualidade". O Brasil era uma nação "sexólatra", que idolatrava o sexo e necessitava de "libertação" nesta área. Agradeço a participação de Paulo Victor Leite Lopes, Ana Paula B. Soeiro e Camila Sampaio, graduandos do Bacharelado em Ciências Sociais da Uerj, pela participação neste evento e também pela ajuda na localização de material bibliográfico e sistematização de banco de dados.

11 As obras datam de 1975 a 2003. Os autores são pastores ou líderes religiosos atuantes em aconselhamento a homossexuais. As filiações religiosas não estão explícitas nos textos. Contudo, há referências a algumas denominações (Assembléia de Deus, Sara Nossa Terra, Presbiteriana e outras).

12 Ver testemunhos publicados no site do Moses (www.moses.org.br).

13 Teologia difundida entre os evangélicos que enfatiza a necessidade de "lutar contra o demônio, que estaria presente em qualquer mal que se faz, em qualquer mal que se sofre e, ainda, na prática de religiões não cristãs" (Mariz, 1999, p. 34).

14 Refiro-me a um conjunto de entrevistas coletado entre os anos de 2002 e 2005, com homossexuais masculinos, oriundos de denominações pentecostais da Baixada Fluminense, periferia do Rio de Janeiro.

15 O discurso católico concebe a homossexualidade como comportamento que interrompe o circuito da reciprocidade do amor divino, como práticas que expressam um "amor auto-centrado", que contraria o princípio da reprodução (expressão máxima do amor de Deus) e devem ser objeto de contenção.

16 Entre os autores estrangeiros há uma maior simetria na problematização das práticas homossexuais masculinas e femininas. Contudo, pretendo fazer uma alusão à cura da homossexualidade com base também na literatura estrangeira, restringindo $\mathrm{O}$ tema à homossexualidade masculina.

17 Justino tem uma atuação convicta em métodos de reversão da homossexualidade na articulação entre psicologia e religião. Nesse sentido, aparece ligada ao Corpo de Psicólogos e Psiquiatras Cristãos (CPPC), advogando à sua categoria de profissionais o direito de tratar de homossexuais em terapias de cunho religioso.
18 Referência a um grupo de auto-ajuda destinado a reordenar a conduta sexual de homossexuais, que contou com auxílio profissional de psicólogos evangélicos.

19 As expressões cura, libertação e recuperação aparecem com certa recorrência no universo religioso, com sentidos correlatos. No presente artigo, contudo, esboço apenas alguns aspectos específicos, na busca de uma compreensão do fenômeno da cura da homossexualidade.

20 O autor refere-se ao abandono do uso de gírias comumente utilizadas no meio homossexual.

21 Sobre o assunto, ver Rebecca Brow (1998) e Neuza Itioka (1993).

22 Foucault (2002), ao analisar as origens históricas da confissão católica, considera que esta institui a revelação obrigatória da sexualidade. A noção é apropriada pelos evangélicos e recriada em contexto pentecostalizado. Nesse sentido, cura espiritual e libertação podem ser atingidas mediante uma confissão dos pecados e de sua renúncia proferida em ritos específicos.

23 Quebrantamento é categoria nativa que alude à necessidade de submeter a Deus emoções e desejos individuais do antigo eu (não convertido). As metáforas de prostrar-se, humilhar-se, quebrar-se são referidas a esse desejo de submissão a Deus. 


\section{HOMOSSEXUALIDADE, GÊNERO E CURA EM PERSPECTIVAS PAS- TORAIS EVANGÉLICAS}

\section{Marcelo Natividade}

Palavras-chave: Pentecostalismo; Homossexualidade; Cura espiritual; Gênero; Religião; Direitos humanos.

Este artigo focaliza as formas de regulação da sexualidade em perspectivas pastorais evangélicas a partir da análise de textos normativos. O autor discute ainda noção de cura da homossexualidade. O material etnográfico é composto por livros e artigos brasileiros e estrangeiros, selecionados a partir do mapeamento do universo editorial evangélico e do monitoramento do conteúdo de sites que oferecem aconselhamento e tratamento a homossexuais em uma perspectiva religiosa. Os dados foram coletados entre 2003 e 2004.

\section{HOMOSEXUALITY, GENDER, AND CURE IN EVANGELICAL PASTORAL PERSPECTIVES}

Marcelo Natividade

Keywords: Pentecostalism; Homosexuality; Spiritual cure; Gender; Religion; Human rights.

This article focuses on the ways of sexuality regulation in evangelical pastoral perspectives from the analysis of normative texts. The author also discusses the notion of cure of homosexuality. The ethnographic material is composed both of books and Brazilian and foreign articles selected from a mapping out of the evangelical editorial universe and of the monitoring of contents at sites offering counseling and treatment to homosexuals from a religious perspective. Data was collected between 2003 and 2004.
HOMOSEXUALITÉ, GENRE ET GUÉRISON SELON LES PERSPECTIVES DES PASTORALES ÉVANGELIQUES

Marcelo Natividade

Mots-clés: Pentecôtisme; Homosexualité; Guérison spirituelle; Genre; Religion; Droits humains.

Cet article analyse, à partir de textes normatifs, les moyens de contrôle de la sexualité selon la perspective des pastorales évangéliques. L'auteur aborde également la notion de guérison de l'homosexualité. Le matériel ethnographique est composé de livres et d'articles brésiliens et étrangers, sélectionnés à partir d'une recherche à propos de l'univers éditorial évangélique et du suivi du contenu de sites qui offrent conseil et traitement aux homosexuels suivant une perspective religieuse. Les données ont été recueillies entre 2003 et 2004 . 